\title{
Organizing Knowledge in Museums: A Review of Concepts and Concerns
}

\author{
Hannah Turner \\ Simon Fraser University, School for Interactive Art and Technology, \\ 250-13450 102nd Avenue, Surrey, BC, Canada, V3T 0A3, \\ Primary Email: <Hannah.trnr@gmail.com>, \\ Secondary Email: < Hannah_turner@sfu.ca>
}

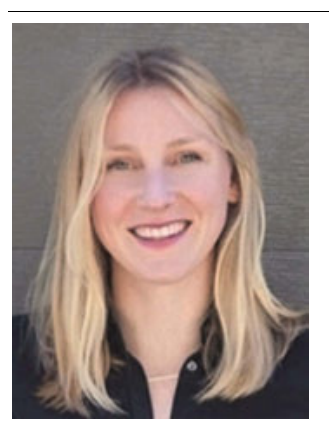

Hannah Turner is a postdoctoral fellow in the Making Culture Lab at the School of Interactive Arts and Technology (SIAT) at Simon Fraser University in Surrey, BC. She received her PhD in 2015 on the topic of knowledge infrastructures and museum cataloging from the University of Toronto. Her research has explored histories of ethnographic documentation and the computerization of museum catalogs. She is currently working on writing histories of virtual reality in museums, and understanding the social and ethical issues when documenting museum objects using 3D scanners.

Turner, Hannah. 2017. “Organizing Knowledge in Museums: A Review of Concepts and Concerns.” Knowledge Organization 44(7): 472-484. 104 references.

Abstract: This paper critically analyzes and ties together contemporary perspectives in information studies, science and technology studies, knowledge organization and indigenous postcolonial theory (particularly concerning ontologies and knowledge organization) and defines the development of a field of thought for museum knowledge organization. It also proposes a selection of terms or ideas for the field of knowledge organization in museums and begins to historicize the development of the field. This paper calls attention to the practical and intellectual issues raised when other knowledges "meet" museums systems as well. The history of the study of museums within Foucauldian thought, the origins of contemporary ideas of the socio-technical, the utility of the metaphor of infrastructure, and the notion of technological affordance are all ideas that have been useful in understanding standardized systems in large institutional repositories, especially as museum collections continue to be digitized and circulated widely by communities. This paper plots the issues we as scholars and professionals should be attentive to when studying the organization of knowledge in museums by developing a theoretical standpoint that engages seriously with the ethics and politics of knowledge.

Received: 23 June 2017; Revised: 19 September 2017; Accepted: 30 September 2017

Keywords: knowledge, knowledge organization systems (KOSs), museums, indigenous approaches

\subsection{Introduction}

The topic of organizing knowledge in museums has been recently addressed (Duarte and Belarde-Lewis 2015; MacNeil 2016; Marty and Jones 2008; Turner 2015), and increased attention is being paid to developing this subject within a field of study and a history of ideas. Much like in the field of archives and libraries, histories of knowledge organization systems in museums should be written, and this should be done with attention paid to the power relationships that are embedded into systems, taxonomies, and technologies (see Gilliland 2012). This paper situates the museum in a material semiotic perspective to take up some of the challenges posed in the literature to historicize and destabilize knowledge organization, particularly concerning the information records, databases, and catalogs. This paper ties together contemporary perspectives in sciences studies, feminist and post- colonial theory, and information studies. The goals are theoretical: to begin to define the development of a field of thought as scholars continue to question if museum standards of description should change through time, or if taxonomic reparations should be considered part of the reconciliatory work of museums today (Adler 2016, for example). Increased attention to the practical and intellectual issues raised when other knowledges "meet" museums systems is necessary, particularly in the context of changing digital technologies. What set of critical terms and texts aid us in understanding and theorizing the museum as a place of knowledge organization and creation, not only display? In developing this theoretical scaffolding, this paper proposes a set of issues we as scholars and professionals should be attentive to when studying the organization of knowledge in museums.

These questions do not arise in a vacuum and are inspired by an approach to understanding the socio- 
technical born out of epistemologies developed in actornetwork theory, activity theory, classification studies, media studies, science and technology studies, and feminist and Indigenous approaches to knowledge. Concepts like infrastructure (Edwards et al. 2009), technological affordance (Gibson 1979; Leonardi and Barley 2008; Nagy and Neff 2015), ontology (Almeida Campos and Gomes 2016), and material or media durability (Dourish and Mazmanian 2013; Gitelman 2006, 2014; Law 1992, 2008; Turner 2016a) call to the social relations made stable by knowledge organization systems more broadly, yet these are sparingly applied to the study of museum catalogs and information structures. These terms connote the relations created or formalized by technologies, which is a specific philosophical standpoint that takes up calls to recognize and destabilize the infrastructures that sort and differentiate our worlds (Doyle 2013; Adler 2016). These are not inherently bad, of course, and as Mary Douglas (1970) famously argued (and as many others have recognized), classifications, taxonomies, schemes, and formats are necessary for the functioning of distinct systems and collective wholes or even communities. Plotting these socio-technical systems, whether recognized as such or not, is not an easy task and requires speaking with individuals, observing work patterns, understanding the technologies used (cataloging databases for example), and conducting archival research.

Creating any knowledge organization scheme is a formative and world-building exercise, and in the world building of systems, other worlds are put aside. This is not necessarily a problem, in fact, it is necessary for the functioning of the whole, as socio-technical knowledge frameworks (like other knowledge frameworks) are defined by their boundaries. Museum knowledge is no exception. As heterogeneous assemblages (literally and metaphorically), no two are alike. Museums are social institutions. In different contexts, they can provide education, provoke or elicit emotional responses, or cultivate third-spaces or contact zones which can cause visitors to question their relations to the material world around them. They can shed light on historical facts, injustices, pleasures, etc. Yet, all museums and galleries that care for objects rely on pre-existing or pre-defined categories that have shaped a relationship to these objects. The concept of provenance, for example, did not come from "on high," it arose out of a long-held situated perspective about the nature of objectivity, rationality, and truth (for example, see Bearman and Lytle 1985). Investigating the categorical levels at which we might think through an object, artwork, biological specimen or archaeological artefact is an important and necessary step towards more equitable and ethical approach to knowledge organization broadly (Guimarães et. al. 2016; Littletree and Metoyer 2015).
This paper proposes a small contribution to the field of knowledge organization and museum studies by tying together some threads of thought that have appeared in the literature. I first plot the history of ideas concerning museums and knowledge organization with a focus on the concept of the Foucauldian episteme and how this was taken up by museum scholars like Tony Bennett and Eileen Hooper-Greenhill. Out of this review, I propose a socio-technical framework for understanding knowledge organization in museums, and build upon this by introducing the concept of infrastructure. Third, I raise a series of key terms or issues that are at stake when we think about organizing knowledge in museums: the roles of classification and technological affordance, and the "data" of museum work. Last I raise debates in post-colonial knowledge practices. A major aim of this paper is to point to other work that has done the kind of cataloging histories or taxonomic otogenies that others have proposed (e.g., Tennis 2002). To what forms can we pay attention when studying the organization of knowledgeparticularly in these heterogeneous museum institutions? What set of critical terms and texts aid us in understanding and theorizing the museum as a place of knowledge organization and creation, not only display?

\subsection{Historicizing knowledge organization in museums}

Museums can be both a field of study and topic of interest and have been studied in a variety of ways, many of which I have covered elsewhere (Turner (2016b, 102):

In one respect, the history of museums is one of colonial collections and engagements with otherness-encounters with cultures, peoples, and objects previously unknown. Historicizing how collections were amassed and how a study of material culture developed and became normalized is important to a holistic understanding of the development of modern ethnographic museums. In another respect, the history of museums is one of documentation, authority, and control.

This posits museums as key sites of knowledge production and circulation and sets the stage for an understanding of the "background" work of museums as an important site for understanding knowledge organization more broadly. Concepts of the socio-technical, largely developed in activity theory and expanded upon by actor network theory, allow an analysis of museums that pays attention to the sets of standards, classifications, and technologies that structure museum work as well as the practices of individuals and the interpersonal or bureaucratic 
negotiations that exist. A significant commitment of socio-technical theory, whether situated in activity theory (AT), actor network theory (ANT), or in science and technology studies (STS) research, is to understand cognition as socio-technical, and that the "social" is mediated not only by objects but by history as well. Inspired by cultural historical activity theory (Engeström 2001; Luria 1976; Vygotsky 1962) and the concept of the Foucauldian episteme (Foucault 1970), this framework considers the situated practices around technologies that influence the organization of knowledge.

\subsection{Epistemes and ordering museum knowledge}

Catalogs, lists, digitized databases, work practices, recording keeping-these classification tools and practices come to structure our organizations and modes of being, and museums are replete with examples. Much scholarship has sought to understand the connection between museums and organizing the world to understand how and why certain knowledge systems take precedence over others (Barringer and Flynn 1998; Charmantier and Müller-Wille 2014; Daston and Galison 2010; Daston and Park 1998; Hooper-Greenhill 1992; Krajewski 2011; Pratt 1992). This resonates strongly with the concept of the "episteme," which was developed by Foucault and later applied by Hooper-Greenhill in her historical review of the origins of museum thought. Hooper-Greenhill argued that the origins of the modern museum were made possible by a set of certain epistemic assumptions that developed throughout the nineteenth century (HooperGreenhill 1992). The influence of the developments made in the natural sciences, particularly the theory of evolution (Bennett 2004), had a great impact on the development of the human sciences and the creation of anthropology as a discipline (Dias 1998; Jenkins 1994; Hinsley 1981; Parezo 1987; Sheets-Pyenson 1988; Willmott 2005; Verdon 2006). This in turn affected the way objects were collected, perceived, and cataloged.

For Foucault (1970), the act of ordering and classifying is connected to the production of knowledge more broadly, and that which is considered to be rational is deeply connected to relationships of domination and subjugation. Knowledge and rationality themselves come to be defined within "epistemes," which are "positive and productive sets of relations within which knowledge is produced and rationality is defined." Connected (loosely) to epochs (time periods), epistemes are defined by their flux as terms shift and change and as difference is constantly repositioned (Hooper-Greenhill 1992, 12). Each episteme has particular characteristics. Epistemes are the temporal and intellectual conditions of possibility wherein a thing, an object, or a fact can be said to be true or false. In other words, objects are defined differently in different epistemes - the path to knowing is fundamentally different. Part of Foucault's project was to inject historicity into the study of the past to create the conditions for an "effective history". Foucauldian epistemes can be read as provocations to understanding a historiography of the museum (Hooper-Greenhill 1992). Certainly, he allows for the possibility of understanding historical context when doing research on museums, and he arguably provides a methodology for doing so.

Hooper-Greenhill (1992), following Foucault, has used the concept of "episteme" to understand issues of historical classification in museums. Hooper-Greenhill, like others, focuses primarily on the ordering of space within the gallery; but her work has significant ramifications for a study of documentation systems. Her argument, that an "enlightenment episteme" made the concepts of collecting and curating for modern science the core of the museums' faculties, is a relevant analysis. She argues that knowledge became a commodity that museums could offer $(1992,4)$, and that each episteme through time would allow for a certain kind of object to be more desirable for museums. In this sense, and as Tony Bennett (1994; 2004) has argued, classification made it possible to theorize the unseen, to make the invisible visible. It worked to solidify the relationships between the marginalized and powerful. In the modern episteme, proximity on a large classification scale was not seen as enough, and the human sciences developed. The concept of episteme is relevant and many disciplines find their predecessors within Foucauldian thought. Importantly, Hooper-Greenhill argues that the "classical" episteme as identified by Foucault saw museums adopt scientific taxonomies as the rubrics or standards by which all material culture was documented. As she notes (192), knowledge became "a pure tabulated relationship of words and things." However, as Parry (2007) notes, in the history of the museum in the first half of the twentieth century, museum knowledge was less scientific in its approach to the study of culture. Museum knowledge, or knowing by association and through object study, he argued (51), is akin to knowledge practices in earlier Renaissance contexts, in which it was the curators who ordered and conducted object studies in a highly personalized and contextualized way.

\subsection{A socio-technical approach to museum knowledge organization}

I argue that contemporary approaches to studying knowledge organization museum settings must consider their material semiotics and infrastructures - terms derived both from information studies but that have deeper histories in social studies of science and anthropology. Claims that 
concern the metadata of museum records and the impact digitization has made on knowledge organization are built atop other assumptions about the relationship of technologies and people. A socio-technical approach can craft the history of a system or a network and provide key insights into how politics or ethics are inscribed upon, or in, technologies.

Bowker and Star $(1999,156)$ have argued that studying documentation systems and infrastructures is of ethical importance and that "we have a moral and ethical agenda in our querying of these systems. Every standard and each category valorizes some point of view and silences another. This is not inherently a bad thing-indeed, it is inescapable."

Understanding museum catalogs as both historical documents and as sites of negotiation and performance is situated most clearly in theories of the "sociotechnical." Concepts of the socio-technical are strongly connected to social constructivist understandings of knowledge and meaning. Often, this theoretical schema is seen to be informed predominately by actor network theory and activity theory. Activity theory, which has been primarily adopted within the educational learning sciences, is a foundational theoretical advancement in cognition that sees the development of meaning in the mind as a primarily social and cultural process, put forward originally by Vygotsky (1962). For Vygotsky, cognition is a "mediated activity," requiring that tools, be they artefactual or psychological or "technical," mediate the activity or learning. This is often represented as a subject, object, and "mediating artifact" triad (Engestrom 2001).

As Engestrom argues $(2001,134)$, the inclusion of cultural artifacts in a Cartesian dualist model of cognition and human action was revolutionary as it allowed for the individual to be understood within a wider social and cultural context and enabled an understanding of the "society" needed to account for the individuals and their artefacts. Engestrom defines activity theory by its focus on the collective and mediated activity of a system, its recognition of the multiple nature of communities, their historicity, contradiction, and the possibility of transformation (136). The social systems, or "activity systems," are thus reliant on actors, their artefacts, and their historical "underpinnings." The historicity of activity systems requires an understanding (137) of the "local history of the activity and its objects, and a history of the theoretical ideas and tools that has shaped the activity." This historical approach to understanding the socio-technical has clear resonance with the Foucauldian concept of the "episteme." These tenets of activity theory, particularly cultural historical activity theoretical approaches, have all helped craft contemporary ideas of the "socio-technical" as a complex assemblage of technologies (objects) and people.
I consider actor network theory (ANT) as an analytic tool rather than a purely theoretical concept (Latour 2005; Law and Hassard 1999), but it is primarily influenced by the work of activity theory, and has since evolved into a robust literature that examines the relations and agencies of socio-technical networks. Research in ANT is largely assumed to be a heterogeneous body of literature. It is most aptly described as a methodology and a sensibility. The concept of material semiotics is a refined version of a much broader set of ANT literatures and was developed through the work of Callon (2005), Latour (1987), Latour and Woolgar (1986), and Law and Hassard (1999). Material semiotics is the mapping of relationships between things and concepts. Studies in material semiotics (Law 2008) pay close attention to the semiotic relations, the heterogeneous actors, and the "stuff" of a network. Latour (2005) has traced the "social" through networks of relationships between objects and people (actors). Together with Woolgar (1986), Latour has shown how certain objects or ways of speaking about things have become naturalized or standard, and then are made immutable and translatable across time and space. Other work has explored how laboratories, hospitals, and other places of work involve networks of human and non-human actors (Latour 2005). Principally influenced by post-structuralist notions of discourse (Foucault 1970), material semiotics grew out of a frustration with notions of how science comes to create claims to truth and draws attention to the material relations that are formed through contact with technologies of documentation and systems of thought (Law and Hassard 1999). Most importantly, studies in material semiotics document not just why networks work, but how.

ANT and material semiotic scholarship have developed several fundamental concepts relevant when studying socio-technical networks and systems. First, ANT theories have addressed the presence or function of nonhuman actors in complex webs of meaning and intentionality, not unlike earlier activity theory definitions of the mediated activity (Latour 2005; Engestrom 2001), although they are not the first to do so (Todd 2016). Second, within ANT perspectives, all knowledge is understood to be local (Bowker 2008), and knowledges are enacted through everyday practices of socio-technical relationships or assemblages (Law 2008; Mol 2002; Suchman 2007; Harrison, Byrne and Clarke 2013). Third, the concept of the "black box" draws attention to the fact that value systems and politics can be affixed or attributed to material objects and technologies (Latour and Woolgar 1986). Through simplification, actors find themselves in networks whose composition they rarely understand or are aware of, and thus the political and ethical ramifications become subsumed or embedded into the technologies or objects that they use, design, or employ. 


\subsection{Museums as data producers?}

Within any episteme or socio-technical milieu, different kinds of evidences are brought into relief as a way of organizing and explaining the world. Historians of science have mapped the ways in which facts and data become constructed through complex negotiations of nature, technology, and observers (Daston and Galison 2010; Knorr-Cetina 1981; Poovey 1998). These ideas were first expressed by Fleck (1979) and elaborated upon by Kuhn (1996), who described a paradigm as thought patterns and standards that identify what counts as a legitimate contribution to knowledge in a field. Scholarship since has sought to dismantle the Kuhnian deterministic paradigmatic approach, and much of this work has been positioned as social constructivist science (Hacking 2000; Harding 1991). Recent work has addressed how museums acted as scientific laboratories (Bennett 2005), and this calls the museum as a producer of scientific knowledge into question.

Many scholars have been influential in crafting ideas of how science is practiced and how scientific objects come into being, both in a historical and contemporary sense (Latour and Woolgar 1986; Knorr-Cetina 1981; Lemov 2011; Mol 2002; Law 2012). Of relevance is the work of Daston $(2000,3)$, who examined the historical practices of the physical sciences. Daston posited that scientific objects "can be simultaneously real and historical" and assumed that reality is "a matter of degree" but that phenomena become more real as they are "woven into scientific thought and practice" (1). Daston's call for an applied metaphysics requires that serious attention be paid to specific practices that enable objects or information to come to have meaning. Monstuschi's description and expansion of this idea $(2007,4)$ reflects the notion that scientific objects are indeed different from regular objects, they may or may not be "quotidian" things but are "elusive and hardwon." The material objects in museum collections exist at a middle ground. They are indeed quotidian objects in the most basic sense but are equally constructed by different sets of epistemological understandings of the world.

Building on the scholarship of both Foucault and the material semiotic approaches to understanding sociotechnical systems, Daston and her colleague Galison (2010) expanded the notion of how scientific objectivity came to be accepted as a form of evidence and pedagogy in the physical sciences. They conceptualized that objectivity as a value and a method in the natural sciences is itself historically located, and their work is relevant for histories of scientific observation (within which anthropology is deeply embedded). Daston and Galison reconsidered what empirical, observable reality is and how it came to be practiced in the sciences of the nineteenth century.
In sum, many scholars now agree that concepts and categories such as facts and data and objects are localized and temporal, and that alternative overlapping worlds of knowledge organize the world in radically different ways (Bowker 2005; Daston 2012; Harding 1991; Fujimura and Luce 1998; Ribes and Bowker 2009). The study of the creation or stabilization of knowledge through looking at infrastructures such as standards, categories, and data arrangements can potentially explain how it is that multiple worlds become subsumed into one through normative practice.

\subsection{Infrastructure: a key concept of museum knowledge organization?}

The concept of information infrastructure predominately originates from work in studies of science and organization (Bowker et al. 2010; Edwards et al. 2009; Jackson et. al. 2007; Star and Ruhleder 1996). I have begun to theorize the relationship between infrastructure and knowledge organization (Turner 2016a, 164), describing how it is "often used to address the large-scale yet often inconspicuous material networks that structure our world, such as roads and Internet cables." The origins were better plotted in Bowker and Star's seminal volume, Sorting Things Out (1999), where they elaborated on the concept of infrastructure to show how it is fundamentally linked to questions of power. They argued that classification systems and standards were integral to any working infrastructure (16). Infrastructures are frequently invisible, but are "highly politically and ethically charged" (147) and are a kind of work that goes unnoticed and naturalized. They only become visible when an infrastructural inversion occurs, which is when the normalized system comes to the foreground in a kind of gestalt switch. As they articulated (34), this is done by "looking closely at technologies and arrangements that, by design and by habit, tend to fade into the woodwork." The consequences of existing and invisible information infrastructures are that the latent meanings behind the information schemes go unnoticed yet remain politically important.

Mai $(2004,42)$ reminds us that "the determination of categories in classification is related to the historical, social, and cultural context in which the classification system is created and used." Latour's classic example of black-boxed technologies examines the practical politics of a "doorcloser" in the context of a work environment. In this analysis, owing to the technological affordances of the walls, doors are a necessity, and so are the door-closers that keep them in place (Latour 1987). Through a series of mediated technologies, the door remains shut, and these technologies often go unnoticed to those who pass through these doors regularly. The underlying machinery in tech- 
nology only becomes visible when something does not work, or the normally functioning whole ceases to do so (Star 1992). It is only in the breakdown of the system where the mechanism, in this case, the door closer, becomes visible and able to be articulated. This is known as an infrastructural inversion; it is in the breakdown of the system that true interconnectedness is visible. To perform an infrastructural inversion, one must forcibly "break the door closer" to examine the mechanisms of sociotechnical systems that we are often unaware of.

Recent work has raised the question of whether knowledge organization schemes function as information infrastructures or knowledge infrastructures in libraries (Doyle 2013, 110) and museums (Beltrame 2012b; Beltrame and Jungen 2013; Turner 2016a). Doyle has focused on the educational components of library information organization, such as the distinction between hidden curriculum and official knowledges. She acknowledges that knowledge organization schemes, the standards and naming conventions in library classification, function as invisible but pervasive infrastructures. She argues that there are larger, underlying constraints that shape the system of knowledge in a library setting. Doyle has commented (113) on Bowker and Star's notion of infrastructure, arguing that it has changed the notion of classification "from a predominantly decontextualized and cognitive model to one that recognizes the situated, collective and historically contingent nature of classification systems anchored in social practice and politics."

Classificatory schemes and modes of organizing knowledge make up part of working information infrastructures, and Bowker and Star $(2000,147)$ read the explosion in classificatory principles in the late nineteenth century as both political forces and "organizing rubrics for complex bureaucracies." Understanding classification systems and categories is important for understanding the infrastructure of museum information management and knowledge production, particularly in the context of ubiquitous attempts at digitization across all public institutions. Likewise, Lampland and Star have argued (2009) that information infrastructures rely heavily on standards, that is, classification schemes and standardized documentation practices that are part of everyday practice. Some of these are formal, some of them are not. While formalized standards are present in museums in the form of digital standards for information sharing, such as file names, for the most part, many museums rely on a set of informal standards to conduct cataloging practice and have done so throughout their histories. These informal standards take the form of continually updated controlled vocabularies, ad hoc naming conventions, lookup lists, and inventory control terms.

\subsection{Classifying, cataloging, standardizing}

Tennis has recently argued $(2015,245-6)$ that there are several different metatheoretical approaches to understanding classification theory. First order classification theory, for example, examines how classification schemes are constructed and used, where second order is concerned with how schemes change over time and how they interoperate and how they change depending on context. Foundational classification theory is what I am concerned with here; that is, attention is paid to the process and the philosophical and definitional aspects of classification (246). In museums, classification schemes are everywhere, and they are historical. Often, words, phrases, and ordering languages and even concepts like provenance and donor come from pre-existing ideas about what an object is and how it should be preserved, often situated in nineteenth century ideals about objectivity and value (as explored above).

Much of the study and critique of classification schemes and naming standards (Furner 2007; Lee 2011; Doyle 2013; Lampland and Star 2009; Olson 1993; Olson and Ward 1997) has been directed at standard or formal classification schemes used in libraries and in medical classification literature, for example (Bowker and Star 1999; Mol 2002). To organize and describe the object of study in the library, such as the book, article, or multimedia object, librarians rely on a variety of descriptive standards that are suggested by federal and international regulating bodies. Similarly, archives rely on international standards of arrangement and description. Museums, however, are unique among other cultural institutions, as their systems of organization consist of some formal or standardized methods, but generally rely on ad hoc systems of cataloging that are specific to each individual institution. Furthermore, the naming and organization practices have varied through time and vary significantly between institutions. This is, in part, because cataloging the plethora and variety of materials in museums, from artworks to natural history to paleo-biological species, in one classification system would be impossible. Museums are defined by the objects they hold, and naming strategies in an art museum will differ fundamentally from those in a science museum. Even within one museum, each department will rely on distinct classifications and standards; for example, biological specimens are cataloged according to standards monitored by a variety of scientific councils. Furthermore, in the library setting, when using the Dewey Decimal Classification, for example, two copies of the same book are classified identically, but it is currently understood that each object in a museum has a unique and specific history that ultimately shapes the final record individually. 
Museum catalogs make use of a variety of standard practices, nomenclatures, and classifications that are seen as industry standards and are adopted de facto by many museums internationally. Despite the existence of several standards developed through the International Organization for Standardization (ISO), each museum has its own specific method of cataloging objects, which relies on a variety of different practices. These shift historically and are often aligned with previous practice in the institution. However, there are a variety of standards that are designed to aid museum workers in using unified object terminologies and object classifications. Further, specific software often relies on built-in nomenclature standards. For example, the Museum System (a popular collections management software), includes the Getty Research Institute's $A r t$ \& Architecture Thesaurus (AAT) and Thesaurus of Geographic Names (TGN). KeEMu integrates the Spectrum Standard, another collections management procedural standard supplemented by definitions of information element groups relating to museum objects launched in 1994 and is a published volume of best practices and naming strategies. Collections management software allows for modification by the local institution, so many of these database tools make use of already existing systems of description and naming that have been used as a part of institutional normalized practice. There are a plethora of nomenclatures and classification systems that seek to provide a framework for museum collections; but due to the fact that museums incorporate a variety of types of classes of material (unlike a library), there is no one system or standard that accounts for the information associated with all objects, across all time periods, in museums over the world.

Relatively little scholarship has focused on the historical precedents of these systems. Exceptions include the work of Bearman and Trant (1999), Marty (2007), and Parry (2007; 2013; 2010). Bearman's work in particular has focused on museum digitization. Parry $(2007,137)$ has traced a historical narrative of computer technologies in museums and argued that there are "profound discontinuities between how a museum and a computer both function." Although he devotes much attention to the history of museum computing, his analysis does not extend to the historical lineage of cataloging prior to the development of the database. Material-semiotic relationships are important when looking at the development of any new technology. Thus, from a conceptual theoretical framework that approaches knowledge creation as part of a socio-technical system and a heterogeneous network, this dissertation seeks to understand how museum knowledge is created, organized and instantiated in the institution.

\subsection{Technological affordance}

As socio-technical studies in classification show, there is a dual and reciprocal relationship between the technologies of knowledge organization and the individuals who are responsible for completing these tasks. The ideas that technologies have particular physical qualities is not new. However, there has in recent years been a focus on addressing or escaping the "problems" with a kind of simple socialconstructivism. As Nagy and Neff have recently argued $(2015,3)$ : "affordance is based on a contradiction that it presumes, but does not confront, about the distinction between matter and mind, materiality and discourse." As a general concept, affordances and constraints define the material bounds of the object or technology, where the technology in conjunction with a user allows for a specific engagement. Affordances do not necessarily prescribe this engagement, but rather they are the loose bounds wherein which human action can shape or change the outcome. Much of this thinking arose from design theory; namely the work of Gibson (1979) and Norman ([1988] 1990; 1999) and has since shifted to the domain of sociology, information and science studies. For Gibson, as Hutchby (2001) explains, the concept of affordance can reconcile constructivism and realism, where technologies are not seen to have what he calls "essential technical" properties (Hutchby 2001) but affordances. They have the (444) "functional and relational aspects that frame, while not determining the possibilities for agentic action in relation to an object." Seen in the context of work in materiality (or the renewed Western interest in object-human relations), affordances (Nagy and Naff 2015, 4) "can and should be defined to include properties of technologies that are 'imagined' by users, by their fears, their expectations and their uses, as well as by those of the designers." While Nagy and Naff are interested in defining the term affordance, they also complicate its use, attending to the "latent, assumed, false, hidden, masked, and blackboxes much of socio-technical systems," and that these theories have often overlooked our effectual and emotional aspects of engagement of technologies. These issues are not necessarily new or a product of computing environments, and there have been many initiatives that have worked to remedy this aspect of organizing knowledge in the context of past practice or legacy data. Hine $(2005 ; 2006,271)$ following other historians of science such as Galison (1997) and Lenoir (1998), has argued that technologies like digital databases do not ipso facto change scientific practice; but that they raise key issues that were always at stake like frameworks for evaluation and work practices and bring to light the uncomfortable practices of the past. Strasser (2012, 311), a historian of science, has also argued that natural history collections always included data (drawings, notes, 
associated information) and that scientists have been organizing data just as they have physical collections for some time.

What does this mean for museum knowledge organization? It means that when working with a catalog system, or defining a new terminology, many museum staff will know or feel what Bowker and Star have called $(1999,117)$ "the inescapable inertia of terms or categories already in use." That the affordances of the technical systems, whether these be catalog cards, ledger books, digital databases, or even the broader bureaucracy, shape in some part the use and engagement with these systems. As I have noted elsewhere when individuals work in museum knowledge organization systems, they are inevitably struggling with the legacies of past practice and the technological systems they use. Technologies and their "affordances" set the conditions of possibility with which to engage in the work: be it cataloging, exhibition planning, or even hiring. What have come to be seen as mundane work practices in museums are highly mediated, important activities. In this way, affordances are also performative (Leonardi 2011, 148).

\subsection{Postcolonial, feminist, Indigenous knowledge organization}

It is incredibly important to understand feminist and Indigenous scholarship when it comes to studying museum knowledge organization, particularly when museum collections still hold a significant about of objects collected from Indigenous communities around the world. It is also important to consider the significant contributions of scholars whose work has perhaps fallen outside of traditional academic cores. Intellectual colonialism is a significant effect of many knowledge organization fields, and has been recently and fruitfully addressed (Cherry and Mukunda 2015; Duarte and Belarde-Lewis 2015; Lougheed et. al., 2015; Whaanga et. al., 2015).

Indigenous scholars have been actively crafting the theories of decolonization and marginalization for some time and have critiqued (Smith 1999, 19) the fact that "imperialism frames the Indigenous experience." Much of this critique has been in part inspired by earlier work in feminist theory, standpoint theory, and critical race studies (Harding 2002; Wylie 2003). Feminist theory and methodologies have been foundational in calling attention to the subaltern, peripheral narratives and inequality generally (Haraway 1988; 1994). Standpoint theory aims to disrupt the normative by making one aware and conscious that norms exist, with the hope that in doing so, non-normative possibilities can coexist (Harding 2002). This can be characterized as an outcome of feminist and post-colonial science studies that seek to articulate the vantage point of the oppressed. More broadly, however,
Harding suggests that it is an attempt to take conventional social relations and practices as problematic (2002, 50). Standpoint theories assume, as Ann Doyle has argued, "an inseparability of power and knowledge" which has been a central theme to other work in the history of science, specifically with Foucault (Doyle 2013).

Indigenous knowledges are often seen to exist as "opposed" to Eurocentric and scientific knowledges. One critique of this dichotomy is that of Indigenous métissage, put forward by Donald (2009; 2012) but elaborated upon by Doyle (2013). Métissage can be defined (Donald 2012, 535) as a conceptual trope and practical tool, whose central tenets involve an "ethical relationality" that "does not deny difference, but rather seeks to understand more deeply how our different histories and experiences position us in relation to each other." Further, as Donald argues, métissage can be used to defy or resist the priority and authority given to official texts $(2009,537)$. In my own work, métissage has been a way forward when thinking through the ethical outcomes of organizing both collections and the information about them.

In a recent article, feminist Indigenous scholar Todd $(2016,8)$ critiqued the academy's preoccupation with using and Indigenous concepts without recognition, particularly in the realm of anthropology and science studies. Regarding a lecture by Latour on climate change in the anthropocene, she argues:

The ones we credited for these incredible insights into the "more-than-human," sentience and agency, and the ways through which to imagine our "common cosmopolitical concerns" were not the people who built and maintain the knowledge systems that European and North American anthropologists and philosophers have been studying for well over a hundred years, and predicating many of their current "aha" ontological moments (or re-imaginings of the discipline) upon ... But the structures that produce talks like the one I attended make it easy for those within the EuroWestern academy to advance and consume arguments that parallel discourses in Indigenous contexts without explicitly nodding to them, or by minimally nodding to Indigenous intellectual and political players. Because we still practice our disciplines in ways that erase Indigenous bodies within our lecture halls in Europe, we unconsciously avoid engaging with contemporary Indigenous scholars and thinkers while we engage instead with eighty year old ethnographic texts or two hundred year old philosophical tomes.

Todd's critique cannot be understated, and is critical if we are to continue our paths as academics who "do" intellectual history. In the history that I have been crafting con- 
cerning knowledge organization in museums, many of the theoretical paradigms, ideas, and terms come out of a male and western centric intellectual history. Demonstrating Indigenous roots to these ideas, particularly of the socio-material, is necessary if we are to move forward from previous physical and intellectual colonialism across all spheres. Why is this important for museum knowledge organization? As Olson (2002) noted, our power to name is a means of structuring reality, and we must begin treating users as non-homogenous. There have been decades of work from Indigenous, postcolonial perspectives that take this into account and into the heart of their work, too many to name here. When thinking through the philosophical and pragmatic issues at stake concerning museums and organizing knowledge, we find crucial contributions from these philosophies that deserve full recognition (Parent 2015). Two key issues have come to the fore. First, the idea that Indigenous and feminist philosophies may better account for (or at least have been and can be a foundation for thinking about) how knowledge operates more broadly and this must be taken up by nonIndigenous scholars in a serious way (Holbraad et. al. 2014; Hunt 2014); and secondly, that the decolonization or the redress of knowledge organization schemes is now urgently required for reconciliation (Truth Reconciliation Commission of Canada 2015). This comes at a risk, as Todd $(2015,9)$, following Watts, acknowledges:

There is a very real risk to Indigenous thinking being used by non-Indigenous scholars who apply it to Actor Network Theory, cosmopolitics, ontological and posthumanist threads without contending with the embodied expressions of stories, laws, and songs as bound with Indigenous-Place Thought (Watts 2013: 31) or Indigenous self-determination.

Following Sundberg (2014) and Watts (2013), Todd urges non-Indigenous scholars to account for location and Indigenous place-thought. As a non-Indigenous settler academic, I hope that this work does reinforce this exact anxiety, but instead, in a small way, provides some context about why a discussion such as this must be relevant for museum knowledge organization. As museums that hold Indigenous cultural property but also natural historical specimens, art, and biological materials, these issues are certainly paramount. Collections have been framed in a way that separates the natural world from the humanmade, and this reinforces a disconnect between memory, people, and the land. There are also important examples of projects and museums that are seeking to reframe this in the context of standard museum practice and organization. These range from providing links to existing museum content and organizing objects from different perspectives digitally, to making the case for different systems of classification altogether, and by providing object based language resources. One notable example is the recent Digital Sq'éwlets project (digitalsqewlets.ca) that re-frames archaeological objects as belongings or A:wkw', and categorizes them according to activities important to the Stó:lo people of the Fraser River Valley in British Columbia, Canada (Lyons et al. 2016). Another example of a projects that connect objects to communities through digital networks include the Reciprocal Research Network (rrncommunity.org) (Rowley 2013), and there are many others that seek to improve Indigenous access to library and archival materials by re-organizing collections according to Indigenous knowledge organization (Christen 2008; Lee 2011; Littletree and Metoyer 2015; Swanson 2015; Whaanga et al 2015, Willmott et al. 2016, for example).

Understanding how Eurocentrism is constructed and made to last in knowledge organizing institutions like museums is seen through the lens of post-colonial decolonization theory, but is only part of a larger struggle attended to by Indigenous peoples themselves in a variety of ways: acts of resistance through filmmaking, performance art, journalism, repatriation, and other academic disciplines. Todd's critique centres on the academy as a white public space; where Indigenous or non-white voices are continually erased and obfuscated. When thinking about classification, categorization, nomenclatures, naming, and organizing, attention should be turned to these issues, despite that they are not (unfortunately) new, but deep seated, histori$\mathrm{cal}$, and ever-present. Indeed, much work is already underway to challenge western centric classification schemes across locations (Bardenheier, Wilkinson, and Dale 2015, for example). Concepts like the métissage draw attention to the points at which Indigenous peoples' histories meet with, in this case, museums' forms of authoritative control.

\subsection{Conclusion}

The goal of this paper has been to situate the study of museum knowledge organization in a body and a history of theory and approaches, often seen as disparate or disconnected. Many omissions are likely present, but the intention was to present to scholars and non-academics a variety of issues that can, and should consider when thinking about these systems. For example, little was written about the history of museum data management, and there is a long trajectory of working through knowledge organization systems in museums. For example, there are many examples of shared data or linked open data initiatives (see Isaac and Haslfhofer 2013). Of course, the specificities of each individual museum knowledge organization differ, and each different collections management system makes use of different standards and termi- 
nologies as each museum deals with different collections. The purpose was to draw together some of the key themes and terminologies employed to act as a wayfinding device when it comes to thinking about museums as bureaucratic institutions in the context of history: as socio-technical infrastructures, classificatory ordering devices, data producers, and communities of individuals. The idea that our technologies afford us the conditions of possibility for future relations is one way to understand the socio-technical aspect of museum knowledge work, and it is a key term that deserves more philosophical work. I also hope to have raised some questions for future scholarship and critical thought. In defining the field of museum knowledge organization, what can we learn from work with the "data" of museums, the cataloging systems and organization models developed in earlier decades? What is the legacy of this data? Do we need more locally appropriate classification schemes or more universal standards? What are the intellectual merits and limits of both?

\section{References}

Adler, Melissa. 2016. "The Case for Taxonomic Reparations." Knowledge Organization 43:630-40.

Almeida Campos, Maria Luiza de, and Hagar Espanha Gomes. 2017. "Ontology: Several Theories on the Representation of Knowledge Domains." Knowledge Organization 44:178-86.

Bardenheier, Penelope, Elizabeth H. Wilkinson and Te Aupōuri Hēmi Dale (Te Rarawa). 2015. "Ki te Tika te Hanga, Ka Pakari te Kete: With the Right Structure We Weave a Strong Basket." Cataloging \& Classification Quarterly 53, nos. 5-6: 496-519. doi:10.1080/01639374. 2015.1008716

Barringer, Tim and Tom Flynn, eds. 1998. Colonialism and the Object: Empire, Material Culture and the Museum. Museum Meanings. London: Routledge.

Bearman, David A., and Richard H. Lytle. 1985. "The Power of the Principle of Provenance." Archivaria 21:14-27.

Bearman, David A., and Jennifer Trant. 1999. "Interactivity Comes of Age: Museums and the World Wide Web." Museum International 51, no. 4:20-24.

Bennett, Tony. 1994. "The Exhibitionary Complex." In Culture/Power/History: A Reader in Contemporary Social Theory, ed. Nicholas B. Dirks, Geoff Eley, and Sherry B. Ortner. Princeton Studies in Culture/Power/History. Princeton, NJ: Princeton University Press, 123-54.

Bennett, Tony. 2004. Pasts Beyond Memory: Evolution, Museums, Colonialism. Museum Meanings. London: Routledge.

Bennett, Tony. 2005. "Civic Laboratories: Museums, Cultural Objecthood and the Governance of the Social."
Cultural Studies 19:521-47. doi:10.1080/0950238050036 5416

Bowker, Geoffrey. C. 2005. Memory Practices in the Sciences. Inside technology. Cambridge, MA: MIT Press.

Bowker, Geoffrey. C., Karen Baker, Florence Millerand and David Ribes. 2010. "Toward Information Infrastructure Studies: Ways of Knowing in a Networked Environment." In International Handbook of Internet Research, ed. Jeremy Hunsinger, Lisbeth Klastrup and Matthew Allen, 97-117.

Callon, Michel. 2005. "Domestication of the Scallops and the Fishermen of St Brieuc Bay." Knowledge: Sociology of Knowledge and Science 5:207.

Charmantier, Isabelle, and Staffan Müller-Wille. 2014. "Carl Linnaeus's Botanical Paper Slips (1767-1773)." Intellectual History Review 24:215-38. doi:10.1080/17496 977.2014.914643

Cherry, Alissa, and Keshav Mukunda. 2015. "A Case Study in Indigenous Classification: Revisiting and Reviving the Brian Deer Scheme." Cataloging \& Classification Quarterly 53, nos. 5-6: 548-67. doi:10.1080/01639374.2015.1008 717

Christen, Kimberly. 2008. "Working Together: Archival Challenges and Digital Solutions in Aboriginal Australia." SAA Archaeological Record. 8, no. 2: 21-4.

Daston, Lorraine, ed. 2000. Biographies of Scientific Objects. Chicago: University of Chicago Press.

Daston, Lorraine, and Peter Galison. 2010. Objectivity. New York: Zone Books.

Daston, Lorraine, and Katharine Park. 1998. Wonders and the Order of Nature, 1150-1750. New York: Zone Books.

Dias, Nélia. 1998. "The Visibility of Difference: Nineteenth-Century French Anthropological Collections." In The Politics of Display: Museums, Science, Culture, ed. Sharon Macdonald. The Heritage: Care, Preservation, Management. London: Routledge, 36-52.

Donald, Dwayne. 2009. "Forts, Curriculum, and Indigenous Métissage: Imagining Decolonization of Aboriginal-Canadian Relations in Educational Contexts." First Nations Perspectives 2:1-24.

Donald, Dwayne. 2012. "Indigenous Métissage: A Decolonizing Research Sensibility." International Journal of Qualitative Studies in Education 25:533-55. doi:10.1080/ 09518398.2011.554449

Douglas, Mary. 1970. Purity and Danger: An Analysis of Concepts of Pollution and Taboo. Harmondworth: Penguin.

Dourish, Paul and Melissa Mazmanian. 2013. "Media as Material: Information Representations as Material Foundations for Organizational Practice." In How Matter Matters: Objects, Artifacts, and Materiality in Organization Studies, ed. Paul R. Carlile, Davide Nicolini, Ann 
Langley and Haridimos Tsoukas. Perspectives on Process Organization Studies 3. Oxford: Oxford University Press, 92-118. doi:10.1093/acprof:oso/9780199 671533.003.0005

Doyle, Ann Mary. 2013. "Naming, Claiming, and (Re) creating: Indigenous Knowledge Organization at the Cultural Interface." PhD diss. University of British Columbia. https://open.library.ubc.ca/cIRcle/collections/ ubctheses/24/items/1.0073667

Drabinski, Emily. 2013. "Queering the Catalog: Queer Theory and the Politics of Correction." The Library Quarterly 83:94-111. doi:10.1086/669547

Duarte, Marisa Elena, and Miranda Belarde-Lewis. 2015. "Imagining: Creating Spaces for Indigenous Ontologies." Cataloging \& Classification Quarterly 53, nos. 5-6: 677-702. doi:10.1080/01639374.2015.1018396

Edwards, Paul N., Geoffrey C. Bowker, Steven J. Jackson, and Robin Williams. 2009. "Introduction: An Agenda for Infrastructure Studies." Journal of the Association for Information Systems 10:364-74.

Engeström, Yrjö. 2001. "Expansive Learning at Work: Toward an Activity Theoretical Reconceptualization." Journal of Education and Work 14:133-56. doi:10.1080/ 13639080020028747

Fleck, Ludwik, trans. Fred Bradley, and Thaddeus J. Trenn. 1979. Genesis and Development of a Scientific Fact. Chicago: University of Chicago Press.

Foucault, Michel. 1970. The Order of Things: An Archaeology of the Human Sciences. New York: Vintage.

Fujimura, Joan H., and Henry R. Luce. 1998. "Authorizing Knowledge in Science and Anthropology." American Anthropologist 100:347-60.

Furner, Jonathan. 2007. "Dewey Deracialized: A Critical Race-Theoretic Perspective." Knowledge Organization 34:144-68.

Galison, Peter. 1997. “Three Laboratories.” Social Research 64:1127-55.

Gilliland, Anne J. 2012. "Contemplating Co-Creator Rights in Archival Description." Knowledge Organization 39:340-46.

Gitelman, Lisa. 2006. Always Already New: Media, History and the Data of Culture. Cambridge, MA: MIT Press.

Gitelman, Lisa. 2014. Paper Knowledge: Toward a Media History of Documents. Sign, Storage, Transmission. Durham: Duke University Press.

Guimarães, José Augusto Chaves, Fabio Assis Pinho and Suellen Oliveira Milani. 2016. “Theoretical Dialogs About Ethical Issues in Knowledge Organization: García Gutiérrez, Hudon, Beghtol, and Olson.” Knowledge Organization 43:338-50.

Hacking, Ian. 2002. Historical Ontology. Cambridge, MA: Harvard University Press.
Haraway, Donna. 1988. "Situated Knowledges: The Science Question in Feminism and the Privilege of Partial Perspective." Feminist Studies 14:575-99.

Haraway, Donna. 1994. "A Manifesto for Cyborgs: Science, Technology, and Socialist Feminism in the 1980s." In The Postmodern Turn: New Perspectives on Social Theory, ed. Steven Seidman. Cambridge: Cambridge University Press, 82-115.

Harding, Sandra. 1991. Whose Science? Whose Knowledge? Thinking from Women's Lives. Ithaca: Cornell University Press.

Harding, Sandra. 2002. "Must the Advance of Science Advance Global Inequality?" International Studies Review 4, no. 2:87-105.

Harrison, Rodney, Sarah Byrne, and Anne Clarke, eds. 2013. Reassembling the Collection: Ethnographic Museums and Indigenous Agency. School for Advanced Research Advanced Seminar Series. Santa Fe, NM: School for Advanced Research Press.

Hine, Christine. 2005. "Material Culture and the Shaping of E-Science." Paper presented at First International Conference on e-Social Science June 22-24, 2005 Manchester, UK. https://www.researchgate.net/publication/ 228943645_Material_culture_and_the_shaping_of_escience

Hine, Christine. 2006. "Databases as Scientific Instruments and Their Role in the Ordering of Scientific Work." Social Studies of Science 36:269-98.

Hinsley, Curtis M. 1981. Savages and Scientists: The Smithsonian Institution and the Development of American Anthropology, 1846-1910. Washington, DC: Smithsonian Institution Press.

Holbraad, Martin, Morten Axel Pedersen, and Eduardo Viveiros de Castro. 2014. "The Politics of Ontology: Anthropological Positions." Cultural Anthropology website January 13, 2014. https://culanth.org/fieldsights/ 462-the-politics-of-ontology-anthropological-positions

Hooper-Greenhill, Eilean. 1992. Museums and the Shaping of Knowledge. Heritage. London: Routledge.

Hull, Matthew S. 2012. "Documents and Bureaucracy." Annual Review of Anthropology 41:251-67. doi:10.1146/ annurev.anthro.012809.104953

Hunt, Sarah. 2014. "Ontologies of Indigeneity: The Politics of Embodying a Concept." Cultural Geographies 21, no. 1:27-32. doi: 10.1177/1474474013500226

Isaac, Antoine, and Bernhard Haslhofer. 2013. "Europeana Linked Open Data: data. europeana. eu." Semantic Web 4:291-97.

Jackson, Steven J., Paul N. Edwards, Geoffrey C. Bowker, and Cory P. Knobel. 2007. "Understanding Infrastructure: History, Heuristics and Cyberinfrastructure Policy." First Monday 12, no. 6. doi:10.5210/fm.v12i6.1904

Jenkins, David. 1994. "Object Lessons and Ethnographic Displays: Museum Exhibitions and the Making of 
American Anthropology." Comparative Studies in Society and History 36:242-70.

Knorr-Cetina, Karin. 1981. The Manufacture of Knowledge. Pergamon International Library of Science, Technology, Engineering, and Social Studies. Oxford: Pergamon Press.

Kuhn, Thomas S. 1996. The Structure of Scientific Revolutions, $3^{\text {rd }}$ ed. Chicago: University of Chicago Press.

Latour, Bruno. 1987. Science in Action: How to Follow Scientists and Engineers through Society. Cambridge, MA: Harvard University Press.

Latour, Bruno. 2005. Reassembling the Social: An Introduction to Actor-Network-Theory. Clarendon Lectures in Management Studies. Oxford: Oxford University Press.

Latour, Bruno, and Steve Woolgar. 1986. Laboratory Life: The Construction of Scientific Facts. Princeton, NJ: Princeton University Press.

Law, John. 1992. "Notes on the Theory of the ActorNetwork: Ordering, Strategy, and Heterogeneity." Systemic Practice and Action Research 5: 379-93.

Law, John. 2008. "Actor Network Theory and Material Semiotics." In The New Blackwell Companion to Social Theory, ed. Bryan S. Turner. Blackwell Companions to Sociology. Chichester: Wiley-Blackwell, 141-58.

Law, John, and John Hassard, eds. 1999. Actor Network Theory and After. Boston, MA: Blackwell Publishers.

Lee, Deborah. 2011. "Indigenous Knowledge Organization: A Study of Concepts, Terminology, Structure and (Mostly) Indigenous Voices." Partnership: The Canadian Journal of Library and Information Practice and Research 6, no. 1. https://journal.lib.uoguelph.ca/index. php/perj/article/view/1427/2089\#.WfOuzUzMzjA

Lenoir, Timothy, ed. 1998. Inscribing Science: Scientific Texts and the Materiality of Communication. Writing Science. Stanford, CA: Stanford University Press.

Leonardi, Paul M. 2011. "When Flexible Routines Meet Flexible Technologies: Affordance, Constraint, and the Imbrication of Human and Material Agencies." MIS Quarterly 35:147-67.

Leonardi, Paul M., and Stephen R. Barley. 2008. "Materiality and Change: Challenges to Building Better Theory about Technology and Organizing." Information and Organization 18:159-76. doi:10.1016/j.infoandorg.2008. 03.001

Littletree, Sandra, and Cheryl A. Metoyer. 2015. "Knowledge Organization from an Indigenous Perspective: The Mashantucket Pequot Thesaurus of American Indian Terminology Project." Cataloging \& Classification Quarterly 53, nos. 5-6:640-57. doi:10.1080/01639374. 2015.1010113

Lougheed, Brett, Ry Moran, and Camille Callison. 2015. "Reconciliation through Description: Using Metadata to Realize the Vision of the National Research Centre for Truth and Reconciliation." Cataloging \& Classification Quarterly 53, nos. 5-6:596-614. doi:10.1080/01639 374.2015.1008718

Luria, A. R., trans. Martin Lopez-Morillas and Lynn Solotaroff. 1976. Cognitive Development: Its Cultural and Social Foundations. Cambridge, MA: Harvard University Press.

Lyons, Natasha, David M. Schaepe, Kate Hennessy, Michael Blake, Clarence Pennier, John R. Welch, Kyle McIntosh, et al. 2016. "Sharing Deep History as Digital Knowledge: An Ontology of the Sq'éwlets Website Project." Journal of Social Archaeology 16:359-84.

MacNeil, Heather. 2016. "Catalogues and the Collecting and Ordering of Knowledge (I): Ca. 1550-1750." Archivaria 82:27-53.

Marty, Paul F. 2007. "The Changing Nature of Information Work in Museums." Journal of the American Society for Information Science and Technology 58:97-107. doi:10.1002/asi.20443

Marty, Paul F., and Katherine Burton Jones, eds. 2008. Museum Informatics: People, Information, and Technology in Museums. Routledge Studies in Library and Information Science 2. New York: Routledge.

Mol, Annemarie. 2002. The Body Multiple: Ontology in Medical Practice. Science and Cultural Theory. Durham: Duke University Press.

Montuschi, Eleonora. 2007. "Real, Invented, or Applied? Some Reflections on Scientific Objectivity and Social Ontology." In Contributions to Social Ontology, ed. Clive Lawson, John Latsis, and Nuno Martins. Routledge Studies in Critical Realism 15. London: Routledge, 15-177.

Nagy, Peter, and Gina Neff. 2015. "Imagined Affordance: Reconstructing a Keyword for Communication Theory." Social Media + Society 1, no. 2. doi:10.1177/2056 305115603385

Norman, Donald. A. (1988) 1990. The Design of Everyday Things. New York: Doubleday,

Norman, Donald. A. 1999. "Affordance, Conventions and Design," Interactions 6, no. 3:38-42.

Olson, Hope A. 1993. "Assumptions of Naming in Information Storage and Retrieval: A Deconstruction." In Information as a Global Commodity: Communication, Processing and Use, Proceedings of the Annual Conference of the Canadian Association for Information Science/ Actes Du Congrès Annuel de l'ACSI, St. Francis Xavier University, Antigonish, Nova Scotia. July $12-$ 14, 1993, 110-19. https://www.cais-acsi.ca/ojs/index. $\mathrm{php} / \mathrm{cais} /$ article/view/599

Olson, Hope A. 2002. The Power to Name: Locating the Limits of Subject Representation in Libraries. Dordrecht: Kluwer Academic Publishers.

Olson, Hope A., and Dennis B. Ward. 1997. "Ghettoes and Diaspora in Classification: Communicating Across the Limits." In Communication and Information 
in Context: Society, Technology, and the Professions, Proceedings of the Annual Conference of CAIS / Actes Du Congrès Annuel de l'ACSI, Memorial University of Newfoundland, St. John's, Newfoundland, June 8-10, 1997, 19-31. http://www.cais-acsi.ca/ojs/index.php/ cais/article/view/185

Parent, Ingrid. 2015. "Knowledge Systems for All." Cataloging \& Classification Quarterly 53, nos. 5-6: 703-6. doi:10.1080/01639374.2015.1027985

Parezo, Nancy J. 1987. The Formation of Ethnographic Collections: The Smithsonian Institution in the American Southwest. Tucson, AZ: University of Arizona.

Poovey, Mary. 1998. A History of the Modern Fact: Problems of Knowledge in the Sciences of Wealth and Society. Chicago: University of Chicago Press.

Pratt, Mary Louise. 1992. Imperial Eyes: Travel Writing and Transculturation. London: Routledge.

Ribes, David, and Geoffry. C. Bowker. 2009. "Between Meaning and Machine: Learning to Represent the Knowledge of Communities." Information and Organization 19:199-217.

Rowley, Susan. 2013. "The Reciprocal Research Network: The Development Process." Museum Anthropology Review 7:22-43.

Sheets-Pyenson, Susan. 1988. Cathedrals of Science: The Development of Colonial Natural History Museums during the Late Nineteenth Century. Kingston, ON: McGill-Queen's University Press.

Smith, Linda Tuhiwai. 1999. Decolonizing Methodologies: Research and Indigenous Peoples. London: Zed Books.

Star, Susan Leigh. 1992. "The Trojan Door: Organizations, Work, and the 'Open Black Box."' Systems Practice 5:395-410.

Star, Susan Leigh and Karen Ruhleder. 1996. "Steps Toward an Ecology of Infrastructure: Design and Access for Large Information Spaces." Information Systems Research 7, no. 1:111-34. doi:10.1287/isre.7.1.111

Strasser, Bruno J. 2012. "Collecting Nature: Practices, Styles, and Narratives." Osiris 27:303-40.

Suchman, Lucy. 2007. Human-Machine Reconfigurations: Plans and Situated Actions. 2nd ed. Cambridge: Cambridge University Press.

Tennis, Joseph T. 2002. "Subject Ontogeny: Subject Access through Time and the Dimensionality of Classification." In Challenges in Knowledge Representation and Organization for the 21st Century: Integration of Knowledge across Boundaries. Proceedings of the Seventh International ISKO Conference, 10-13 July 2002 Granada, Spain, ed. Maria J. López-Huertas, and Francisco J. MunozFérnandez. Advances in Knowledge Organization 8. Würzberg: Ergon Verlag, 54-9.
Tennis, Joseph T. 2015. "Foundational, First-Order, and Second-Order Classification Theory." Knowledge Organization 42:244-49.

Todd, Zoe. 2016. “An Indigenous Feminist's Take on the Ontological Turn: 'Ontology' is Just Another Word for Colonialism.” Journal of Historical Sociology 29:4-22. doi:10.1111/johs.12124

Turner, Hannah. 2015. "Decolonizing Ethnographic Documentation: A Critical History of the Early Museum Catalogs at the Smithsonian's National Museum of Natural History." Cataloging \& Classification Quarterly 53, nos. 506: 658-76. doi:10.1080/01639374.2015.1010112

Turner, Hannah. 2016a. "The Computerization of Material Culture Catalogues: Objects and Infrastructure in the Smithsonian Institution's Department of Anthropology." Museum Anthropology 39:163-77. doi:10.1111/ muan.12122

Turner, Hannah. 2016b. "Critical Histories of Museum Catalogues.” Museum Anthropology 39:102-10. doi:10. 1111/muan.12118

Truth Reconciliation Commission of Canada. 2015. Final report of the Truth and Reconciliation Commission of Canada. Volume one, Summary: Honouring the truth, reconciling for the future. Winnipeg: Truth and Reconciliation Commission of Canada.

Verdon, Michel. 2006. "The World Upside Down: Boas, History, Evolutionism, and Science." History and Anthropology 17:171-87. doi:10.1080/02757200600861642

Vygotsky, Lev Semenovich. 1962. Thought and Language, trans. Eugenia Hanfmann and Gertrude Vakar. Studies in Communication. Cambridge: M.I.T. Press.

Whaanga, Hēmi, David Bainbridge, Michela Anderson, Korii Scrivener, Papitha Cader, Tom Roa and Te Taka Keegan. 2015. "He Matapihi Mā Mua, Mō Muri: The Ethics, Processes, and Procedures Associated with the Digitization of Indigenous Knowledge; The Pei Jones Collection." Cataloging \& Classification Quarterly 53, nos. 5-6:520-47. doi:10.1080/01639374.2015.1009670

Willmott, Cory. 2005. "The Lens of Science: Anthropometric Photography and the Chippewa, 18901920." Visual Anthropology 18 (4):309-37. doi:10.1080/ 08949460590958374

Willmott, Cory Ann, Alexandra Taitt, Mary Ann Corbiere and Alan Corbiere. 2016. "Toward Language in Action: Agency-Oriented Application of the GRASAC Database for Anishinaabe Language Revitalization." Museum Anthropology Review 10:91-116. doi:10.14434/ mar.v10i2.19322

Wylie, Alison. 2003. "Why Standpoint Matters." In Science and Other Cultures: Issues in Philosophies of Science and Technology, ed. Robert Figueroa and Sandra G. Harding. New York: Routledge, 26-48. 